\title{
PELATIHAN PEMBUATAN FURNITURE DARI BAHAN LIMBAH KAYU PALLET
}

\author{
Rahmatul Jannatin ${ }^{1}$, Riska Hawinuti ${ }^{2}$, Rifanie Gazalie ${ }^{3}$, M. Firdaus ${ }^{4}$ \\ Politeknik Negeri Banjarmasin ${ }^{1,2,3,4}$ \\ jannatinnaimah@gmail.com ${ }^{1}$ \\ riska_hawiuti@yahoo.co.id ${ }^{2}$ \\ rifanieg@gmail.com ${ }^{3}$ \\ muhammadfirdaus@poliban.ac.id ${ }^{4}$
}

\begin{abstract}
Community Service Partners in this activity are residents of Jalan Safir 2 Griya Permata, Semangat Dalam Handil Bakti Village, Barito Kuala. The purpose of this community service activity is to provide training in the form of making simple furniture using wood pallets that are commonly found around the local community. This activity began with furniture design activities through the preparation of concepts to the implementation of concepts in prototype form. This design is carried out with the aim of utilizing the potential of pallet wood waste that has not been utilized well. The targeted output is products / goods in the form of furniture devices such as multifunction cabinets, cupboards where dispensers, TV cabinets, decorative cabinets, decorative guest tables and chairs and mini sofas. The method used in the activity of Training in Furniture Manufacturing from Wood Pallet Waste Material is manual processing, which starts from the socialization stage to the partners and trainees; determining the type of furniture to determine the tools and materials to be used; furniture design / design process; selection of suitable wood pallet materials; wood cleaning; wood drying: material processing; manufacture and assembly; and the final process is finishing.
\end{abstract}

Keywords: design, pallet wood, furniture

\begin{abstract}
ABSTRAK
Mitra Pengabdian Masyarakat pada kegiatan ini adalah warga masyarakat Jalan Safir 2 Komplek Griya Permata, Desa Semangat Dalam Handil Bakti, Barito Kuala. Adapun tujuan dari kegiatan pengabdian ini adalah untuk memberikan pelatihan berupa pembuatan furniture sederhana menggunakan kayu pallet bekas yang banyak ditemukan di sekitar lingkungan warga. Kegiatan ini dimulai dengan kegiatan perancangan furniture melalui penyusunan konsep hingga implementasi konsep dalam bentuk prototype. Perancangan ini dilakukan dengan tujuan memanfaatkan potensi dari limbah kayu pallet yang belum termanfaatkan degan baik. Output yang ditargetkan adalah produk/ barang berupa perangkat meubel seperti lemari multifungsi, lemari tempat dispenser, lemari tempat TV, lemari hias, meja tamu dekoratif dan kursi tamumaupun sofa mini. Metode yang digunakan pada Kegitan Pelatihan Pembuatan Furniture dari Bahan Limbah Kayu Pallet adalah pemprosesan secara manual, yang dimulai dari tahap sosialisasi kepada pihak mitra dan peserta pelatihan; penentuan jenis furniture untuk menentukan alat dan bahan yang akan digunakan; proses perancangan/ desain furniture; pemilihan bahan pallet kayu yang sesuai; pembersihan kayu; pengeringan kayu: pengolahan bahan; pembuatan dan perakitan; dan proses paling akhir adalah finishing.
\end{abstract}

Kata Kunci: perancangan, kayu pallet, furniture 


\section{PENDAHULUAN}

Mitra Pengabdian Masyarakat pada kegiatan ini adalah warga masyarakat Jalan Safir 2 Komplek Griya Permata, Desa Semangat Dalam Handil Bakti, Barito Kuala. Kawasan Handil Bakti Barito Kuala, sebagai daerah penyangga untuk Kota Banjarmasin, merupakan kawasan yang berkembang, hal ini ditandai dengan makin banyaknya toko-toko besar yang menjual aneka keperluan masyarakat, dari bahan makanan, bahan pertukangan, peralatan mesin dan bahan-bahan meubel, yang sebagian materialnya didatangkan langsung dari pulau Jawa. Dalam proses mobilisasi barang-barang tersebut, para pengusaha menggunakan kayu palet sebagai bahan pengemas barang untuk menjaga kualitas dan kuantitas barang selama proses pengiriman.

Kayu pallet adalah kemasan kayu yang terbuat dari beberapa macam bahan baku, baik kayu murni yang sering dikenal dengan kayu keras, triplex atau multplex dan bahan MDF (melamine). Kayu pallet merupakan salah satu pilihan yang digunakan para ekportir, perusahaan tranpostasi, logistik dan berbagai industri lainnya sebagai media pembawa komoditinya baik untuk keperluan ekspor, transit, pengapalan ataupun untuk pergudangan. Kayu pallet ini biasanya digunakan ketika mengirim barang menggunakan peti kontainer. Sehingga untuk menghindari benturan dan mengurangi resiko kerusakan ketika pengiriman dalam perjalanan, maka barang yang dikirim dibungkus menggunakan kayu pallet.

Kayu pallet merupakan salah satu limbah usaha proses mobilisasi barang yang dapat dimanfaatkan lebih lanjut. Mengingat potensi dari kayu pallet bekas ini yang masih bisa dimanfaatkan menjadi barang turunan maka kami selaku Tim Pengusul tertarik untuk memanfaatkan limbah kayu pallet yang menumpuk di lingkungan warga Handil Bakti, Barito Kuala menjadi produk turunan yang dapat dimanfatkan lebih lanjut. Adapun kegiatan pengabdian ini dimulai dari tahap sosialisasi kepada pihak mitra dan peserta pelatihan; penentuan jenis furniture untuk menentukan alat dan bahan yang akan digunakan; proses perancangan/ desain furniture; pemilihan bahan pallet kayu yang sesuai; pembersihan kayu; pengeringan kayu: pengolahan bahan; pembuatan dan perakitan; dan proses paling akhiradalah finishing.

\section{METODE KEGIATAN}

\section{- Lokasi Pelaksanaan Pengabdian}

Kegiatan Pengabdian kepada masyarakat dengan judul Pelatihan Pembuatan Furniture dari Bahan Limbah Packing Kayu dilaksanakan di Workshop Meubel Rapi Sari Banjarmasin, dengan alamat Jalan Safir 2 Komplek Griya Permata, Desa Semangat Dalam Handil Bakti, Barito Kuala. Kawasan Handil Bakti Barito Kuala.

\section{- Peserta}

Kegiatan ini diikuti oleh masyarakat yang berada di lingkungan Jalan Safir 2 Komplek Griya Permata, Desa Semangat Dalam Handil Bakti, Barito Kuala. Kawasan Handil Bakti Barito Kuala.dengan meminjam Workshop Meubel Mitra 
Karya Banjarmasin dan didukung oleh mahasiswa semester 6 D III Teknik Sipil Politeknik Negeri Banjarmasin

\section{- Metode Pelaksanaan}

Proses pengerjaan sebuah kayu pallet bekas menjadi sebuah furniture walaupun bukan sebuah proses yang panjang jika dibandingkan dengan pengolahan dengan menggunakan kayu log atau kayu mentah, namun tetap membutuhkan ketelitian yang tinggi sehingga bisa dihasilkan furniture dengan kualitas yang baik.

Peralatan yang diperlukan untuk membuat furniture dari bahan pallet antara lain:
a. Gergaji (mesin/ manual)
b. Bor (mesin/ manual)
c. Ketam (mesin/ manual)
d. Klem tang
e. Tatah/ pahat
f. Penghalus (pengampelas mesin/ manual)
g. Ragum
h. Tang
i. Catut
j. Palu
k. Rol meter
1. Penggaris siku

Adapun bahan yang dipergunakan adalah:

a. Bahan utama yaitu kayu yang berasal dari kayu bekas pallet, pilih kayu pallet berasal dari kayu pinus.

b. Bahan penyambung antara lain lem kayu, paku beraneka ukuran, baut, lem korea, pasak dan sebagainya.

c. Bahan finishing antara lain amplas, cat dan thinner serta vernis.

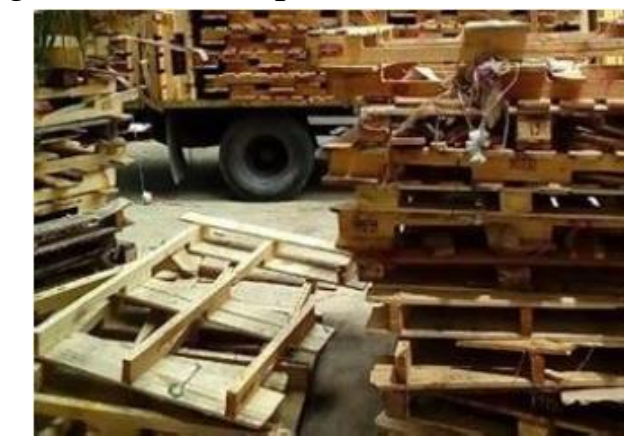

Sumber: Kevin Didenta Bima Priambada, 2017

Gambar 11. Limbah Kayu Pallet yang Belum Dikondisikan 


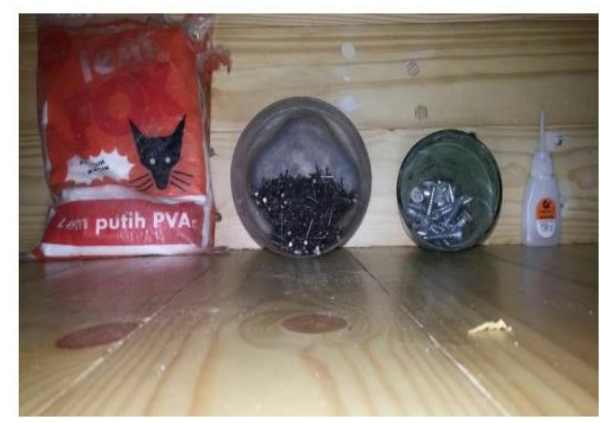

Sumber:Trian Cahyo Utomo, 2017

Gambar 12. Contoh Bahan Penyambung

\section{- Langkah Kerja}

Adapun langkah pelaksanaan kegiatan antara lain:

a. Sosialisasi

b. Penentuan Jenis Furniture

c. Perancangan/ desain

d. Pemilihan Bahan Pallet

Limbah yang dipakai berupa kayu pinus yang didapatkan dari bekas pallet barang. Kayu pinus dipilih sebagai bahan karena memilki tekstur serat kayu yang indah. Jenis kayu lain yang dapat dipergunakan yaitu kayu pinus, selain memiliki tekstur yang indah, jenis kayu ini juga tergolong jenis kayu solid. Pilih kayu dengan kondisi tanpa cacat dan sortir menurut ukuran.

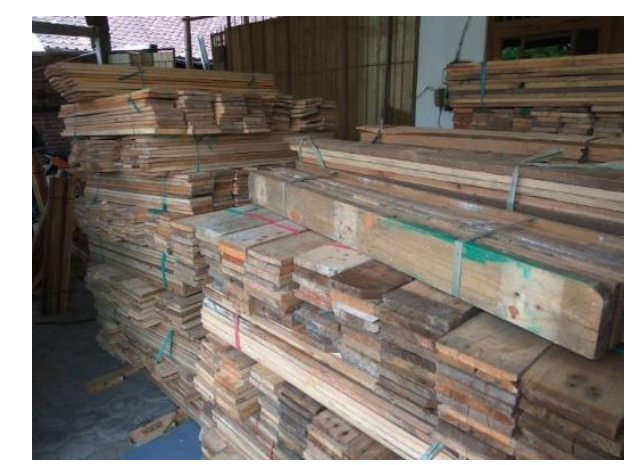

Sumber: Kevin Didenta Bima Priambada, 2017

Gambar 13. Limbah Kayu Pallet yang Telah Dibersihkan dan Dipilah

e. Pembersihan Kayu

f. Pengeringan Kayu

g. Pengolahan Bahan

h. Menghaluskan permukaan kayu

i. Pemotongan kayu

j. Pembuatan Kontruksi dan Perakitan 


\section{k. Finishing}

Proses finishing termasuk pendempulan permukaan material, pengecatan dan pemasangan aksesoris tertentu tergantung konstruksi/ bentuk

\section{HASIL DAN PEMBAHASAN}

\section{Hasil yang Dicapai}

Hasil yang di capai melalui kegiatan Pengabdian Masyarakat dengan judul Pelatihan Pembuatan Furniture dari Bahan Limbah Pallet Kayu yang dilakukan oleh dosen Program Studi Teknik Sipil ini dituangkan dalam bentuk laporan hasil kegiatan pada setiap tahap pelaksanaan sebagai berikut:

a. Koordinasi dengan pihak meubel untuk menentukan tenaga ahli yang diperlukan untuk melatih warga sekitar dalam pemanfaatan kayu palet, serta koordinasi lanjutan untuk menentukan izin peminjaman tempat sebagai lokasi pelatihan warga.

b. Hasil dari diskusi dengan meubel diketahui bahwa limbah kayu palet yang terdapat di sekitar pemukiman warga dapat digunakan sebagai bahan baku untuk furniture dan sangat banyak tersedia di daerah Handil Bakti, Barito Kuala.

c. Pelaksanaan kegiatan pertama dilakukan pada tanggal 28 Agustus 2018 dengan kegiatan pemaparan materi dan pembukaan. Pelaksanaan ini di bantu oleh mahasiswa Poliban. Pelaksaan kegiatan kedua dilakukan pada tanggal 29 Agustus 2018 dengan kegiatan Pembuatan Furniture dari Bahan Limbah Pallet Kayu.

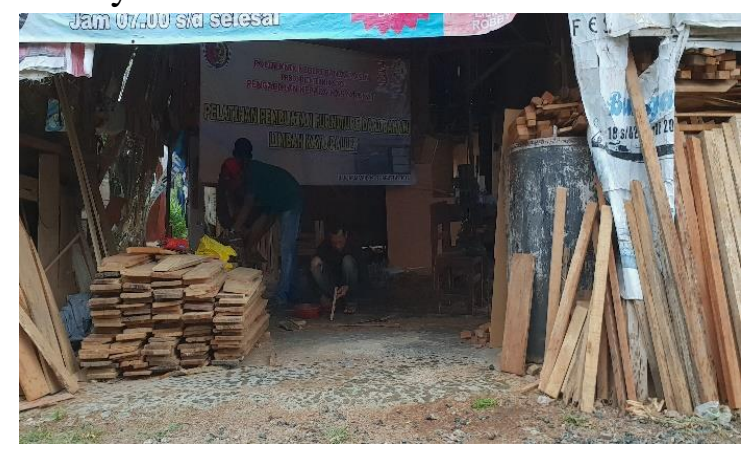

Gambar 14. Lokasi Pelatihan (Meubel Mitra Karya)

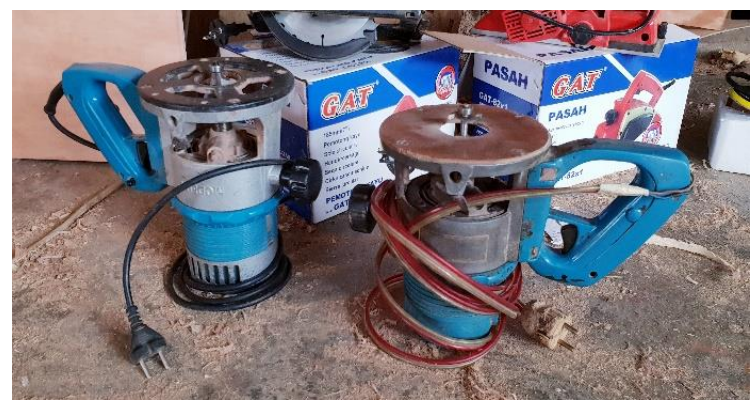

Gambar 15. Persiapan Alat 


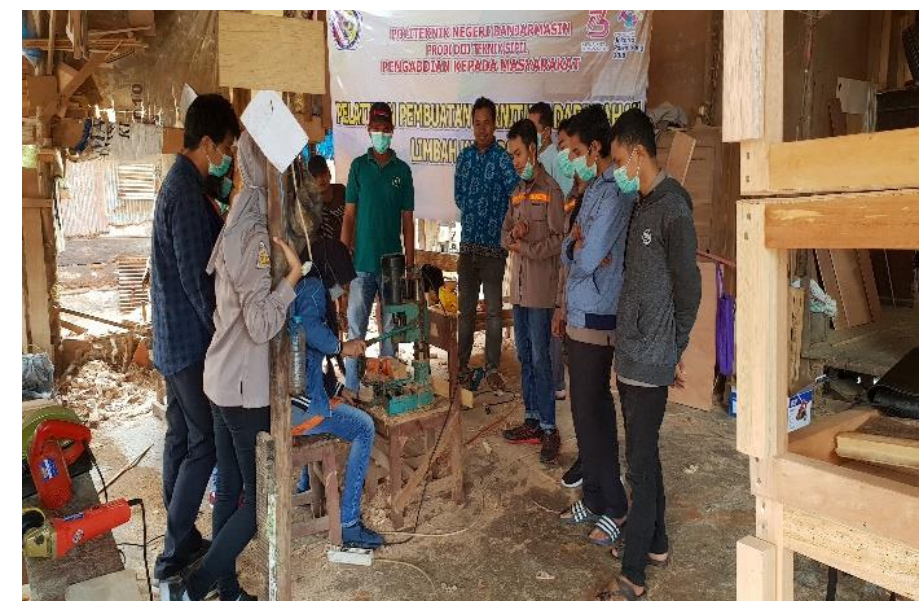

Gambar 16. Pemaparan Materi dan Pengenalan Alat

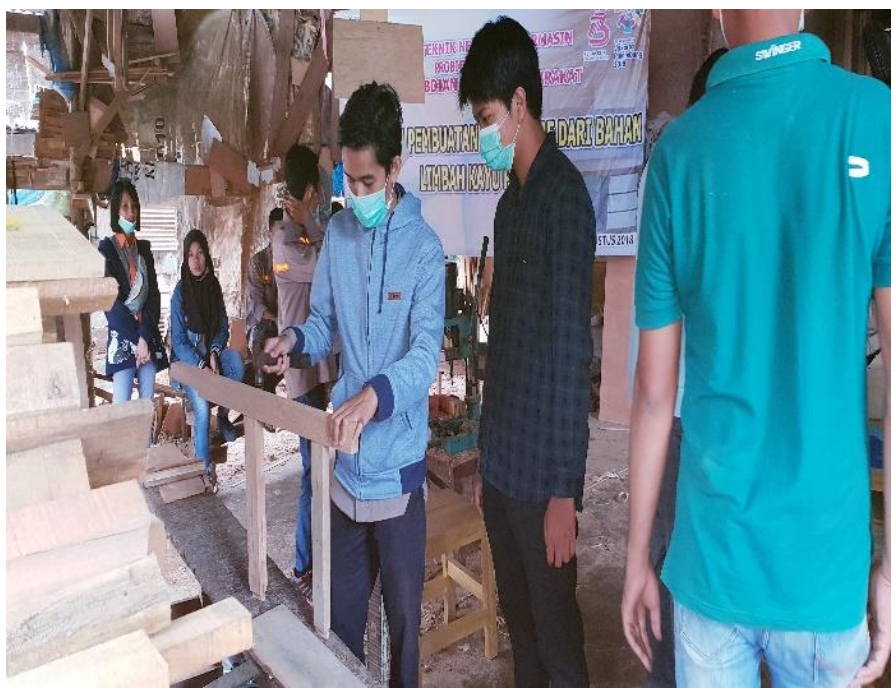

Gambar 17. Proses Pembuatan Kursi

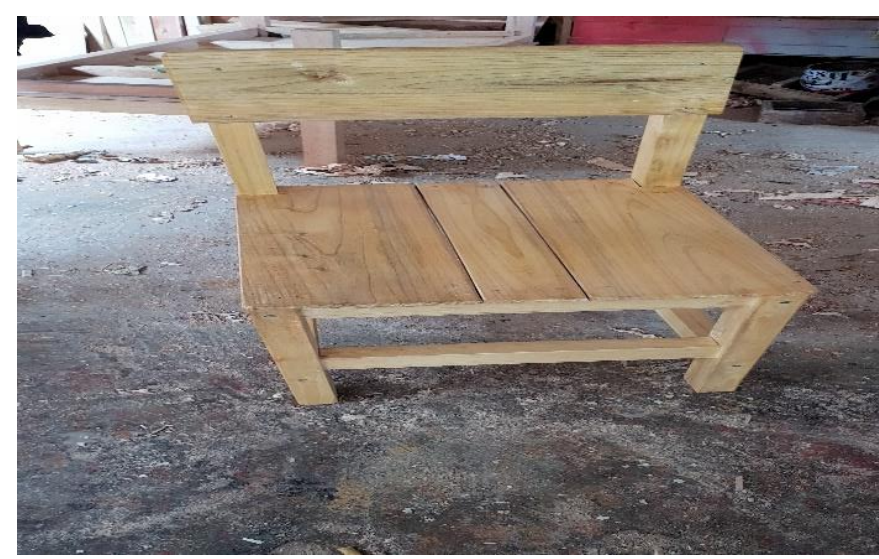

Gambar 18. Hasil Pembuatan Kursi dari bahan Limbah Pallet Kayu 


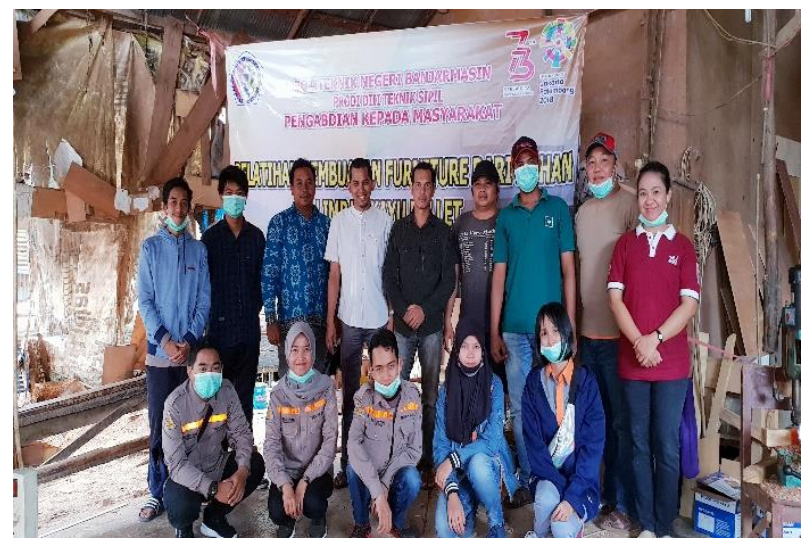

Gambar 19. Dosen Teknik Sipil dan Para Peserta Pelatihan

\section{Solusi dan Luaran yang Dicapai}

Limbah Pallet Kayu yang biasanya hanya dijadikan panggung atau bahkan dibuang sebenarnya dapat digunakan untuk membuat furniture yang menyebabkan nilai ekonomisnya menjadi lebih tinggi. Meubel kayu yang biasanya menggunakan bahan baku dengan harga tinggi dapat menggunakan Pallet kayu sebagai bahan alternatif. Ini juga dapat menguntungkan masyarakat karena harga furniture akan menjadi lebih murah. Pelaksana berharap dan berkeinginan kegiatan ini dapat menjadi solusi berkelanjutan bagi pihak meubel untuk membuat furniture dengan bahan baku Pallet Kayu. Selain dapat lebih menguntungkan, pengurangan limbah tersebut juga baik untuk lingkungan sekitar.

Adapun luaran yang dihasilkan berupa lemari multifungsi, lemari tempat dispenser, lemari tempat TV, lemari hias, meja tamu dekoratif dan kursi tamu maupun sofa mini. Selain itu luaran berupa publikasi berupa jurnal yang diterbitkan oleh Politenik Negeri Banjarmasin (Jurnal IMPACT 2019).

\section{KESIMPULAN}

Hasil yang di capai melalui kegiatan Pengabdian Masyarakat dengan judul Pelatihan Pembuatan Furniture dari Bahan Limbah Pallet Kayu yang dilakukan oleh dosen Program Studi Teknik Sipil ini adalah sebagai berikut :

1. Penggantian bahan kayu selama ini sebagai bahan furniture dapat juga dengan memanfaatkan limbah kayu pallet yang harganya lebih murah dan relative mudah ditemui di sekitar lokasi mitra yang bahkan dibeberapa tempat malah menjadi sampah.

2. Hasil lain yang didapat dari kegiatan pengabdian ini yaitu pengurangan limbah kayu pallet, sehingga dapat termanfaatkan untuk hal yang lebih ekonomis.

3. Pemanfaatan kayu palet dapat dijadikan sebagai alternatif solusi bahan baku furniture berupa material yang ramah lingkungan

4. Peningkatan skill para warga dalam memanfaatkan limbah kayu pallet yang selamaini dibiaran saja menumpuk di sekitar lokasi mitra dan menjadi limbah pabrik. 
5. Beberapa produk yang dihasilkan warga berupaluaran yang dihasilkan berupa lemari multifungsi, lemari tempat dispenser, lemari tempat TV, lemari hias, meja tamu dekoratif dan kursi tamu maupun sofa mini

\section{SARAN}

Berdasarkan hasil yang diperoleh dalam kegiatan Pengabdian Masyarakat ini dapat ditindaklanjuti degan pembimbingan secara berkala hingga keterampilan yang mereka peroleh ini dapat memberdayakan diri sendiri.

\section{DAFTAR PUSTAKA}

Elsafta. 2010. Vacum Dryer. (http://elsafta.wordpress.com/2010/04/21/vakumdryer/, diakses 18 Mei 2019)

Herniwati, Andi. Dkk. 2017. Kelompok Pengrajin Meubel Kayu dalam Pembuatan Sofa Set Multifungsi Berbahan Kayu Limbah Kotak Peti Kemas untuk Rumah Sangat Sederhana (RSS) di Kota Palu. Paper Seminar Nasional Sistem Informasi Tahun 2017, Fakultas Teknologi Informasi, Universitas Malang. (http://seminar.unmer.ac.id, diakses tanggal $20 \mathrm{Mei}$ 2018)

Iensufiie, Tikno. 2008. Furniture dan Handicraft Berkualitas Ekspor. Erlangga. Jakarta.

Priambada, Kevin Didenta Bima. 2017. Pemanfaatan Limbah Kayu Palet dalam Penciptaan Hiasan Terrarium. Tugas Akhir Mahasiwa. Universitas Negeri Yogyakarta. Yogyakarta.

Utomo Cahyo, Trian. 2017. Perancangan Kursi dan Meja Tamu dari Limbah Drum dan Limbah Kayu Palet. Tugas Akhir Mahasiwa. Universitas Negeri Yogyakarta. Yogyakarta.

Sipahelut, A dan Petrussumadi. 1991. Dasar-Dasar Desain. CV Grafik Indah. Jakarta.

Sutanto, Jessica. 2017. Upcycle Limbah Kayu Palet Jati Belanda Menjadi Wadah Modular Serbaguna untuk Anak-Anak (Studi Kasus: Kota Surabaya). $\begin{array}{lllllll}\text { Jurnal Intra } & \text { Vol } & 5 & \text { No } & 2 & \text { Tahun } & 2017 .\end{array}$ (http://publication.petra.ac.id/index.php/desaininterior/article/view/5922540 9, diakses tanggal 21 Mei 2018)

Yuso \& TCH. 2018. Cara Membuat Furniture Rumah Simpel dari Kayu Pallet. (http://www.yuso.co.id/en/article/647/cara-membuat-furniture-rumahsimpel-dari- kayu-pallet, diakses tanggal 18 Mei 201) 